\title{
Nutrition and yield of 'Gigante' cactus pear cultivated with different spacings and organic fertilizer
}

\author{
Paulo E. R. Donato ${ }^{1}$, Sérgio L. R. Donato ${ }^{1}$, João A. Silva ${ }^{1}$, \\ Aureliano J. V. Pires ${ }^{2}$, Raul C. C. Rosa $^{3} \&$ Aureluci A. Aquino ${ }^{1}$ \\ ${ }^{1}$ Instituto Federal Baiano. Guanambi, BA. E-mail: paulo.donato@guanambi.ifbaiano.edu.br (Corresponding author); sergio.donato@guanambi.ifbaiano.edu.br; \\ joao.silva@guanambi.ifbaiano.edu.br; aureluci.aquino@guanambi.ifbaiano.edu.br \\ ${ }^{2}$ Universidade Estadual do Sudoeste da Bahia. Itapetinga, BA. E-mail: aurelianojvp@yahoo.com.br \\ ${ }^{3}$ Embrapa Agrobiologia. Seropédica, RJ. E-mail: raul.rosa@embrapa.br
}

Key words:

Opuntia

plant arrangement

natural fertilization

nutrients

\begin{abstract}
A B S T R A C T
The objective of this study was to evaluate the levels of macronutrients in cladodes and yield of cactus pear, cv. 'Gigante', cultivated with different cattle manure doses and plant spacings. The experimental design was randomized blocks in $4 \times 3$ factorial, with three replicates. The treatments consisted of the combination of four doses of cattle manure $(0,30,60$ and 90 $\mathrm{Mg} \mathrm{ha}^{-1}$ year $\left.^{-1}\right)$ with three spacings $(1.00 \times 0.50,2.00 \times 0.25$ and $3.00 \times 1.00 \times 0.25 \mathrm{~m})$. The contents of macronutrients and dry matter production of cladodes were assessed 600 days after planting. The plant spacings influenced the contents of nitrogen, potassium, calcium and sulfur in the cladodes of 'Gigante' cactus pear and there was interaction between spacing and manure dose for magnesium contents. The increment in cattle manure doses increases the contents of phosphorus, nitrogen, potassium and sulfur in the cladodes. The maximum dry matter production of cladodes is estimated at $21.8 \mathrm{Mg} \mathrm{ha}^{-1}$ year $^{-1}$ at a dose of $71.8 \mathrm{Mg} \mathrm{ha}^{-1}$ year $^{-1}$ of manure.
\end{abstract}

\section{Palavras-chave:}

Opuntia arranjo de plantas fertilização natural nutrientes

\section{Nutrição e produtividade de palma forrageira 'Gigante' cultivada com diferentes espaçamentos e adubação orgânica}

R E S U M O

O objetivo deste trabalho foi avaliar os teores de macronutrientes nos cladódios e o rendimento da palma forrageira 'Gigante' cultivada com diferentes doses de esterco bovino e espaçamentos de plantio. $\mathrm{O}$ delineamento experimental foi em blocos ao acaso no esquema fatorial 4 x 3, com três repetições. Os tratamentos constaram da combinação de quatro doses de esterco bovino $\left(0 ; 30 ; 60\right.$ e $90 \mathrm{Mg} \mathrm{ha}^{-1}$ ano $\left.^{-1}\right)$ com três espaçamentos $(1,00 \times 0,50,2,00 \times 0,25$ e 3,00 × 1,00 × 0,25 m). Aos 600 dias após o plantio foram avaliados os teores de macronutrientes e a produção de massa seca de cladódios. Os espaçamentos influenciaram os teores de nitrogênio, potássio, cálcio e enxofre nos cladódios da palma forrageira 'Gigante' havendo interação entre espaçamento e dose para os teores de magnésio. $\mathrm{O}$ aumento das doses de esterco bovino eleva os teores de fósforo, nitrogênio, potássio e enxofre nos cladódios. A máxima produção de massa seca de cladódios é estimada em 21,8 $\mathrm{Mg} \mathrm{ha}^{-1} \mathrm{ano}^{-1}$ com dose de 71,8 $\mathrm{Mg} \mathrm{ha}^{-1}$ ano $^{-1}$ de esterco. 


\section{INTRODUCTION}

Cactus pear is a xerophyte that is essential as forage reserve in semi-arid regions. Due to its succulence and CAM physiology, it maintains the photosynthetic activity even after five months of drought (Zañudo-Hernández et al., 2010); however, its cultivation for long period requires the adoption of sustainable practices.

The sustainability of agriculture, especially in the Brazilian semi-arid region, is dependent on maintenance of adequate levels or incorporation of organic matter into the soil (Fialho et al., 2013). The supply of organic materials to the soil improves its chemical, physical and biological properties. Additionally, their application results in slow release of nutrients compared with soluble mineral formulations and can promote suppression of pathogens (Geense et al., 2015). The increment in the cattle manure doses applied to the soil improves the structural characteristics of the cactus pear (Donato et al., 2014b) and improves its nutritive value (Donato et al., 2014a). Cactus pear plant spacing has been studied in order to find an arrangement of plants that best suits the production systems (Oliveira Júnior et al., 2009). According to Silva et al. (2014) and Cavalcante et al. (2014), this species increases the yield with higher plant density.

The chemical analysis of the plant tissue is complementary to the soil chemical analysis and to the visual diagnosis and reflects the dynamics of nutrients in the soil-plant system. Thus, this study aimed to evaluate the contents of macronutrients in the cladodes and the yield of 'Gigante' cactus pear cultivated with different cattle manure doses and plant spacings.

\section{Material ANd Methods}

The experiment was carried out at the Federal Institute of Bahia, Campus of Guanambi-BA, Brazil (14 $17^{\prime} 44^{\prime \prime}$ S; $42^{\circ}$ 41' 39" W; $525 \mathrm{~m}$ ). The cactus pear was planted in September 2009 in a dystrophic Red Yellow Latosol (EMBRAPA, 2013). The rainfall along the cultivation, from September 2009 to June 2011, was equal to $1,393.29 \mathrm{~mm}, 611.24 \mathrm{~mm}$ from September 2009 to April 2010 and $782.05 \mathrm{~mm}$ from October 2010 to April 2011.

Before soil preparation, samples were collected in the layer of 0-0.2 $\mathrm{m}$ and subjected to chemical analysis, which showed the following mean results: $\mathrm{pH}$ in water 5.4; available $\mathrm{P} 16.33$ $\mathrm{mg} \mathrm{dm}^{-3} ; 0.29,2.02,0.90,0.16$ and $0.29 \mathrm{cmol}_{\mathrm{c}} \mathrm{dm}^{-3}$, respectively of exchangeable $\mathrm{K}, \mathrm{Mg}, \mathrm{Al}$ and $\mathrm{Na} ; 3.21 \mathrm{cmol}_{\mathrm{c}} \mathrm{dm}^{-3}$ of sum of bases (S); $3.36 \mathrm{cmol}_{\mathrm{c}} \mathrm{dm}^{-3}$ of CEC at soil $\mathrm{pH} ; 1.69 \mathrm{cmol}_{\mathrm{c}} \mathrm{dm}^{-3}$ of $\mathrm{H}+\mathrm{Al}$ and $5.50 \mathrm{cmol}_{\mathrm{c}} \mathrm{dm}^{-3}$ of CEC at pH $7.0(\mathrm{~T}) ; 63.14 \%$ of base saturation $(\mathrm{V}) ; 4.86 \%$ of $\mathrm{Al}$ saturation $(\mathrm{m}) ; 0.67 \%$ of exchangeable sodium percentage (ESP); $14.67 \mathrm{~g} \mathrm{dm}^{-3}$ of organic matter; $0.36,17.61,1.42$ and $6.32 \mathrm{mg} \mathrm{dm}^{-3}$, respectively of $\mathrm{Cu}$, $\mathrm{Mn}, \mathrm{Zn}$ and Fe extracted by Mehlich-1.

The experimental design was randomized blocks in a $4 \mathrm{x} 3$ factorial scheme with three replicates, totaling 36 experimental units. The treatments consisted of four doses of organic fertilization, cattle manure $\left(0,30,60\right.$ and $90 \mathrm{Mg} \mathrm{ha}^{-1}$ year $\left.{ }^{-1}\right)$ and three spacings $(1.00 \times 0.50,2.00 \times 0.25$ and $3.00 \times 1.00 \times$ $0.25 \mathrm{~m}$ ). The total area of the experiment was $2,304 \mathrm{~m}^{2}$ and the plot area was $64 \mathrm{~m}^{2}(16 \times 4 \mathrm{~m})$, with evaluation area of $16 \mathrm{~m}^{2}$ $(8 \times 2 \mathrm{~m})$. The same population density of 20,000 plants ha-1 was maintained in all plant spacings.

The area was subsoiled, plowed, harrowed and furrowed according to the plant spacings. The cattle manure was applied in the planting furrow and incorporated to the soil. The manure showed the following composition: macronutrients $\mathrm{Ca}, \mathrm{Mg}$, $\mathrm{K}, \mathrm{P}, \mathrm{N}$ and $\mathrm{S}$, respectively $1.7,0.2,2.5,4.7,5.2$ and $2.3 \mathrm{~g} \mathrm{~kg}^{-1}$; micronutrients $\mathrm{B}, \mathrm{Cu}, \mathrm{Zn}, \mathrm{Mn}$ and Fe, respectively $2.1,45.2$, $200.5,391.8$ and $1,932.4 \mathrm{mg} \mathrm{kg}^{-1} ; \mathrm{pH}$ of 7.42 and density of 0.38 $\mathrm{g} \mathrm{cm}^{-3}$. The seedlings were selected and placed in the shade for 15 days to heal to cuts and later planted, by burying about $50 \%$ in the soil. Weeds were controlled through manual weeding.

Samples for the determination of contents of nutrients and dry matter were collected at 600 days after planting. The samples were collected in cladodes from the middle of the plants using a hole saw attached to a drilling machine, in a total of 10 samples of $25 \mathrm{~g}$ in each treatment, accounting for 250 $\mathrm{g}$ of green matter (Donato et al., 2014b). After the collection, the material was sliced and dried in an oven at $60{ }^{\circ} \mathrm{C}$ for 72 $\mathrm{h}$ and then ground in a Wiley-type mill with $1.0-\mathrm{mm}$-mesh sieve, packed, identified and sent to the Laboratory of Soil of the EPAMIG of Northern Minas Gerais, for the analytical procedures. Nitrogen $(\mathrm{N})$ was determined through the Kjeldahl method, while phosphorus $(\mathrm{P})$, potassium $(\mathrm{K})$, sulfur $(\mathrm{S})$, calcium $(\mathrm{Ca})$ and magnesium $(\mathrm{Mg})$ were determined through nitric-perchloric digestion, expressed in dag $\mathrm{kg}^{-1}$.

The dry matter was determined according to Silva \& Queiroz (2009). Harvest was performed preserving the three primary cladodes for future regrowth. After weighing, the green matter production was calculated and the dry mass production (DMP) was obtained as a function of water content in the cladodes.

The data were subjected to analysis of variance and, when there was significant effect by $\mathrm{F}$ test, the means of the different spacings were compared by Tukey test at 0.05 probability level, while regression analyses were applied for the different doses of cattle manure, according to the follow-up analysis of the interaction between the factors. The models were selected based on the biological phenomenon, significance of the regression mean square, magnitude of $\mathrm{R}^{2}$ and adjusted $\mathrm{R}^{2}$, and on the significance of the regression parameters by the t-test.

\section{Results AND Discussion}

The doses of cattle manure influenced the P content in the cladode tissues regardless of the spacing used. The $\mathrm{P}$ contents increased linearly in response to the applied doses of manure (Figure 1A), varying from $0.12 \mathrm{dag} \mathrm{kg}^{-1}$, for the treatment without manure, to $0.24 \mathrm{dag} \mathrm{kg}^{-1}$, corresponding to the dose of $90 \mathrm{Mg} \mathrm{ha}^{-1}$ year ${ }^{-1}$ of manure. Therefore, it represents an increment of $100 \%$ in the $\mathrm{P}$ content in the tissue.

According to Dubeux Júnior et al. (2010), the increase in $P$ fertilization leads to greater absorption and accumulation in the dry matter of cactus forage. Dubeux Júnior et al. (2006) found low responses to $P$ in the production of 'Gigante' cactus forage and positive responses only when the contents of $\mathrm{P}$ 


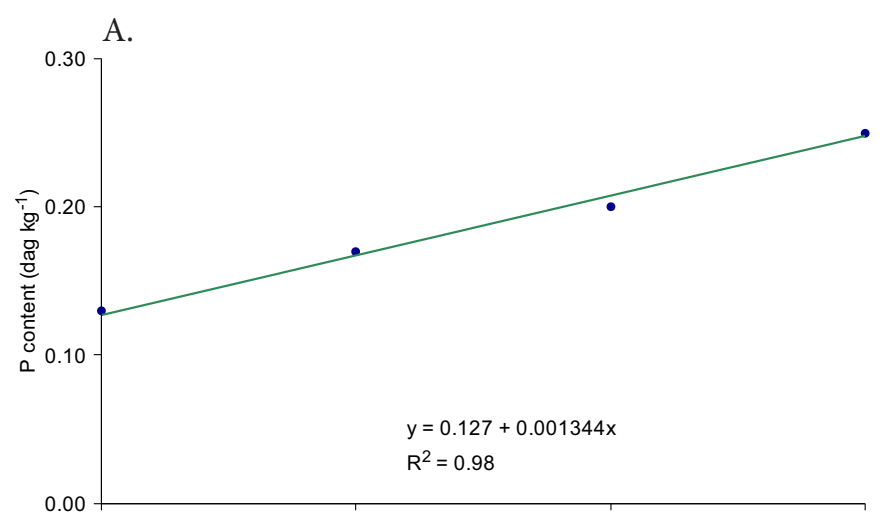

C.

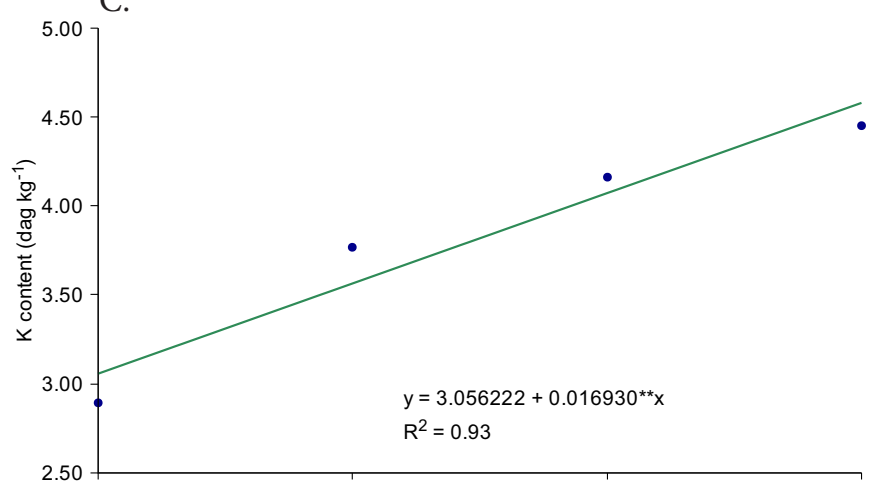

E.

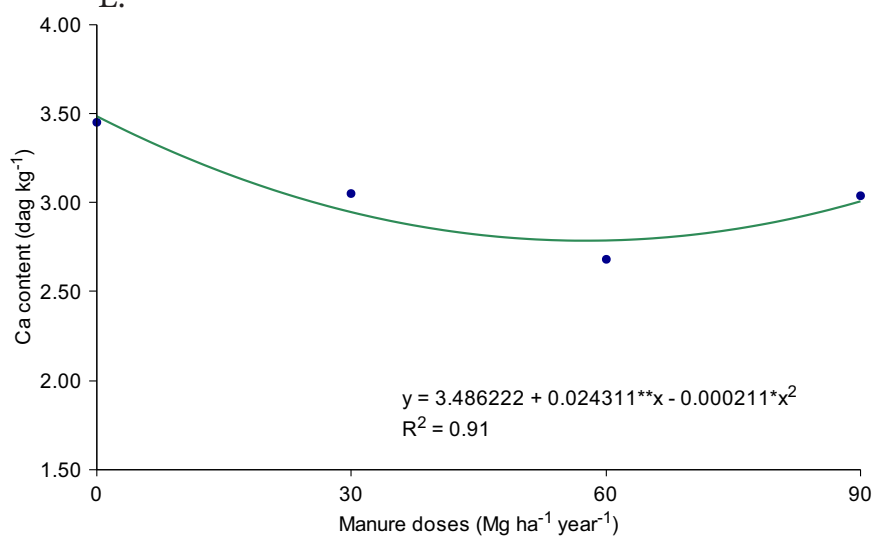

B.

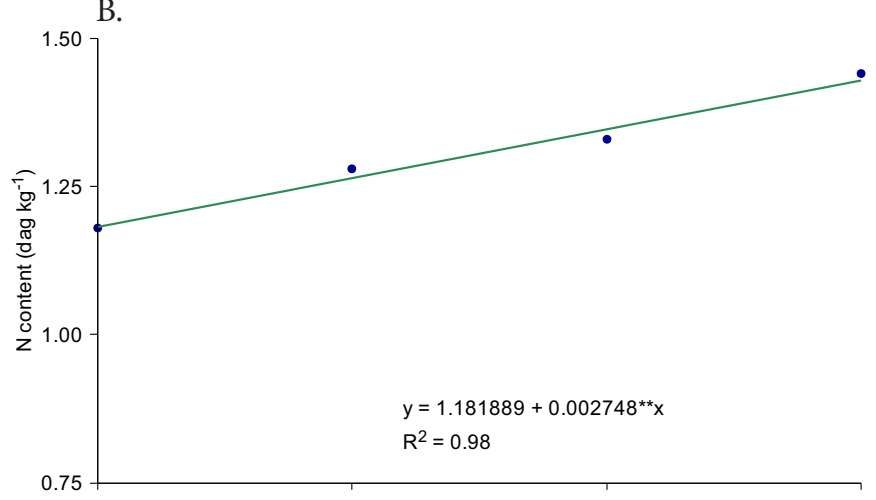

D.

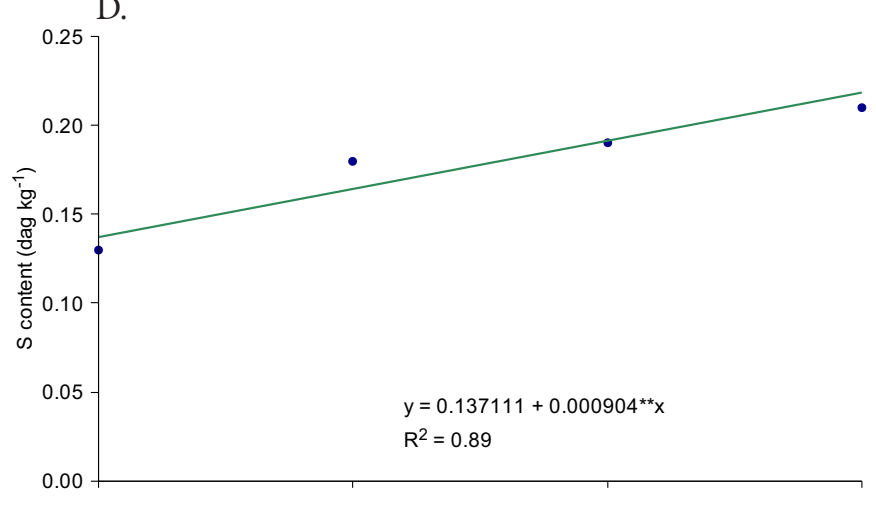

F.

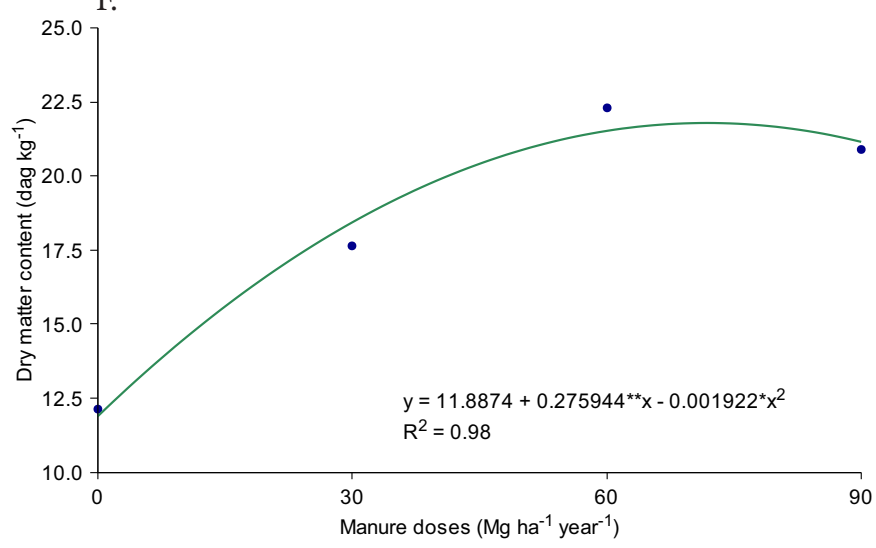

* Significant at 0.05 ** Significant at 0.01 by the t-test

Figure 1. Mean contents $\left(\right.$ dag $\left.\mathrm{kg}^{-1}\right)$ of phosphorus-P $(A)$, nitrogen- $\mathrm{N}(\mathrm{B})$, potassium-K $(\mathrm{C})$, sulfur-S (D) and calcium-Ca (E) and dry matter production (F) at 600 days after planting in cladodes of cactus pear cultivated at different spacings and cattle manure doses

available in the soil were lower than $10 \mathrm{mg} \mathrm{kg}^{-1}$. However, the $\mathrm{P}$ content in the soil before planting, $16.6 \mathrm{mg} \mathrm{kg}^{-1}$, was higher than $10 \mathrm{mg} \mathrm{kg}^{-1}$ in the present study, the addition of $P$ via manure induced greater absorption of this element and its accumulation in the cladodes. This behavior is expected, because, as reported by Souza et al. (2006) and Novais et al. (2007), the addition of organic materials to the soil reduces $\mathrm{P}$ adsorption capacity, increases the available content and promotes greater mobility of soluble organic forms of $\mathrm{P}$ in the soil profile, compared with the applications in the form of mineral fertilizers.

Differences for the contents of N, K, S and Ca in cladode tissues were observed independently between spacings (Table 1) and between manure doses (Figures 1B, 1C, 1D and 1E), without interactions.

The use of different planting densities, or even the plant arrangement in the area, can alter the absorption of nutrients and their contents in plant tissues, as observed in Table 1. This is due to the competition for nutrients between the roots and is related to the mobility of the nutrients in the soil, because, as the plant population increases or the distance between plants decreases, the competition of the roots for nutrients of greater mobility in the soil increases, such as $\mathrm{N}$ and $\mathrm{Ca}$, which are preferentially transported by mass flow or even for somewhat mobile nutrients, such as $\mathrm{K}$ and S. However, for nutrients considered as immobile, preferentially transported through diffusion and of low diffusion coefficient, such as $\mathrm{P}$ and $\mathrm{Zn}$, the competition will only occur in small or minimum intensity and only in the cases in which there is inter-root competition, i.e., in the regions where the roots of two neighboring plants meet (Novais et al., 2007).

The $\mathrm{N}$ content in the cladode tissues of cactus pear was higher at the spacing of $2.0 \times 0.25 \mathrm{~m}$ compared with $1.0 \times 0.5$ $\mathrm{m}$. However, Alves et al. (2007) did not observe differences 
Table 1. Mean contents of macronutrients (dag $\mathrm{kg}^{-1}$ ) in cladodes of cactus pear and dry mass production (DMP) at 600 days after planting, cultivated at different spacings

\begin{tabular}{cccccc}
\hline \multicolumn{1}{c}{$\begin{array}{c}\text { Spacing } \\
(\mathbf{m})\end{array}$} & Nitrogen & Potassium & Sulfur & Calcium & DMP \\
\cline { 2 - 6 } & \multicolumn{5}{c}{${\text { dag } \mathbf{~ k g}^{-1}}$} \\
$1.0 \times 0.5$ & $1.2 \mathrm{~b}$ & $3.2 \mathrm{c}$ & $0.16 \mathrm{~b}$ & $2.8 \mathrm{~b}$ & $21.5 \mathrm{a}$ \\
$2.0 \times 0.25$ & $1.4 \mathrm{a}$ & $4.3 \mathrm{a}$ & $0.19 \mathrm{a}$ & $3.4 \mathrm{a}$ & $18.6 \mathrm{a}$ \\
$3.0 \times 1.0 \times 0.25$ & $1.3 \mathrm{ab}$ & $3.9 \mathrm{~b}$ & $0.17 \mathrm{ab}$ & $2.9 \mathrm{ab}$ & $14.7 \mathrm{~b}$ \\
$\mathrm{CV}(\%)$ & 9.2 & 10.0 & 11.7 & 15.7 & 18.1 \\
\hline
\end{tabular}

Means followed by the same lowercase letter in the column do not differ significantly by Tukey test at 0.05 probability level. CV - Coefficient of variation

in $\mathrm{N}$ content for different spacings and Silva et al. (2012) observed differences with mineral fertilizations, regardless of the spacing. According to this, a lower $\mathrm{N}$ content would be expected in the cladode tissues of the cactus pear cultivated at spacings in which plants are closer along the row and, therefore, the competition is higher, such as $2.0 \times 0.25 \mathrm{~m}$. However, lower $\mathrm{N}$ contents were observed for the spacing in which plants are more distant, $1.0 \times 0.5 \mathrm{~m}$, which can be justified by the fact that, at the moment of fertilization, the cattle manure was distributed on the side of the planting rows. Thus, for the spacing of 1.0 $\mathrm{x} 0.5 \mathrm{~m}$, the manure was distributed in 16 plant rows and at the spacing of $2.0 \times 0.25 \mathrm{~m}$, the same amount of manure was applied in eight plant rows, promoting twice the concentration of manure on the side of the plant row at this spacing, compared with $1.0 \times 0.5 \mathrm{~m}$. Therefore, a higher concentration of nutrients in the soil allowed greater absorption and a probable higher accumulation in the cladodes.

The $\mathrm{N}$ contents increased linearly as a function of the manure doses (Figure 1B), regardless of the spacings. It is estimated an increment of $16.6 \%$ in the $\mathrm{N}$ content in the cladodes, $5.5 \%$ for every $30 \mathrm{Mg} \mathrm{ha}^{-1}$ year $^{-1}$ of manure added to the soil, which corresponds to $130 \mathrm{~kg} \mathrm{ha}^{-1}$ year ${ }^{-1}$ of $\mathrm{N}$. The increase in $\mathrm{N}$ content in the cactus pear with $\mathrm{N}$ fertilization has been reported in the literature (Dubeux Júnior et al., 2006; Silva et al., 2013). The increase in $\mathrm{P}$ and $\mathrm{N}$ contents in the cladodes of cactus pear due to the increment in the manure doses applied to the soil is expected, because approximately $95 \%$ of soil $\mathrm{N}$ is associated with the organic matter and $50 \%$ of $\mathrm{P}$ in the biosphere is found in organic forms (Novais et al., 2007).

The $\mathrm{K}$ contents in the cladodes of cactus pear differed between the plant spacings (Table 1). The highest value occurred in cactus cultivated at $2.0 \times 0.25 \mathrm{~m}$ and the lowest value occurred in plants at spacing of $1.0 \times 0.5 \mathrm{~m}$. Silva et al. (2012) claim that the $\mathrm{K}$ contents in the cladodes, with mean of $2.49 \mathrm{dag} \mathrm{kg}^{-1}$, did not differ between spacings when $100 \mathrm{~kg}$ $\mathrm{ha}^{-1}$ of $\mathrm{K}_{2} \mathrm{O}$ were added. In the present study, the highest and lowest contents of $\mathrm{K}$ and $\mathrm{N}$ in the cladodes occurred for the same spacings.

According to the fitted model, the K content (Figure 1C) of $3.0 \mathrm{dag} \mathrm{kg}{ }^{-1}$ in non-fertilized cladode increased to $4.6 \mathrm{dag} \mathrm{kg}^{-1}$ at the manure dose of $90 \mathrm{Mg} \mathrm{ha}^{-1}$ year $^{-1}$, incrementing by 1.6 dag $\mathrm{kg}^{-1}$, which is equivalent to $0.5 \mathrm{dag} \mathrm{kg}^{-1}$ of $\mathrm{K}$ for every 30 $\mathrm{Mg} \mathrm{ha}^{-1}$ year $^{-1}$ of manure applied to the soil. This manure dose corresponds to $187 \mathrm{~kg} \mathrm{ha}^{-1}$ year $^{-1}$ of $\mathrm{K}$. With the application of $166 \mathrm{~kg} \mathrm{ha}^{-1}$ of $\mathrm{K}$, Dubeux Júnior et al. (2010) found $\mathrm{K}$ content of 3.8 dag $\mathrm{kg}^{-1}$ in cladodes and observed increment in the $\mathrm{K}$ contents (from 4.3 to $5.9 \mathrm{dag} \mathrm{kg}^{-1}$ ) in relation to the $\mathrm{K}$ doses applied to the soil (from 0 to $664 \mathrm{~kg} \mathrm{ha}^{-1}$ of $\mathrm{K}$ ). The greater absorption is due to the higher availability of nutrients from the manure, because the contents of $\mathrm{P}$ and $\mathrm{K}$ increase with the addition of manure, reduce the acidity and make P more available (Caetano \& Carvalho, 2006). This fact was corroborated in the present study, in which the soil pH at 600 days after planting was equal to 5.3 for the non-fertilized area and to 6.0, 6.1 and 6.2 for the areas that received 30, 60 and $90 \mathrm{Mg}$ ha year-1 of manure, respectively. Silva et al. (2007) also reported increase in the contents of $\mathrm{P}$ and $\mathrm{N}$ with the addition of manure.

The cactus pear cultivated at spacing of $2.0 \times 0.25 \mathrm{~m}$ showed higher $\mathrm{S}$ contents (Table 1) in the tissues, compared with the spacing of $1.0 \times 0.5 \mathrm{~m}$. The $\mathrm{S}$ contents (Figure 1D) in the cladodes increased linearly with the applied manure doses, regardless of the plant spacings. The values oscillated from $0.13 \mathrm{dag} \mathrm{kg}^{-1}$, without the addition of manure, to 0.22 dag $\mathrm{kg}^{-1}$, at the dose of $90 \mathrm{Mg} \mathrm{ha}^{-1}$ year $^{-1}$. Silva et al. (2012) observed variations in $\mathrm{S}$ content from $0.12 \mathrm{dag} \mathrm{kg}^{-1}$ to 0.61 dag $\mathrm{kg}^{-1}$ at 620 days after planting, due to the application of formulations containing this macronutrient. The increase in $\mathrm{pH}$ due to the addition of manure increases the availability of $\mathrm{SO}_{4}$ to the plants, for reducing its adsorption and increasing the release of the adsorbed compound, mineralization of organic S (Casagrande et al., 2003) and its mobility in the soil. The mineralization of the $S$ from organic compounds is inverse to their $\mathrm{C} / \mathrm{S}$ ratio, being fast in cattle manures, which justifies the observed results.

The plant spacings influenced Ca contents (Table 1) in the cladodes, regardless of the manure dose. The Ca content in the cladodes at the spacing of $1.0 \times 0.5 \mathrm{~m}$ was lower in comparison to the spacing of $2.0 \times 0.25 \mathrm{~m}$, which was previously justified, differing from the results obtained by Alves et al. (2007), who observed no differences for the Ca contents in cladodes of cactus pear as a function of the spacings.

The Ca contents (Figure 1E) evaluated at 600 days after planting in cladode tissues of cactus pear varied quadratically with the applied doses of cattle manure, regardless of the plant spacing. The fitted model estimates that the manure dose that led to the lowest $\mathrm{Ca}$ contents in the cladode tissues was equal to $57.6 \mathrm{Mg} \mathrm{ha}^{-1}$ year $^{-1}$, reaching the minimum content of 2.8 dag $\mathrm{kg}^{-1}$.

There were interactions between plant spacings and cattle manure doses applied to the soil for the Mg contents (Figure 2) in cladodes of cactus pear evaluated at 600 days after planting. The mean $\mathrm{Mg}$ content in the present study was similar to those reported by Silva et al. (2012) and Alves et al. (2007). However, Alves et al. (2007) observed no effects of plant spacing. The $\mathrm{Mg}$ contents (Figure 2) showed a quadratic response to the cattle manure doses applied to the soil at the spacings of $1.0 \mathrm{x}$ $0.5 \mathrm{~m}$ and $3.0 \times 1.0 \times 0.25 \mathrm{~m}$, while there was model fit for the spacing of $2.0 \times 0.25 \mathrm{~m}$.

The fitted models estimate that the manure doses that promoted the highest $\mathrm{Mg}$ contents in cladodes of cactus pear were 47.6 and $58.3 \mathrm{Mg} \mathrm{ha}^{-1}$ year $^{-1}$ for the spacing of $3.0 \mathrm{x} 1.0 \mathrm{x}$ $0.25 \mathrm{~m}$ in double row and $1.0 \times 0.5 \mathrm{~m}$ in single row. The contents correspond to 1.18 and $1.13 \mathrm{dag}^{-1}$, respectively.

The mean dry matter production (DMP) of the cactus pear differed between plant spacings (Table 1) and between cattle 


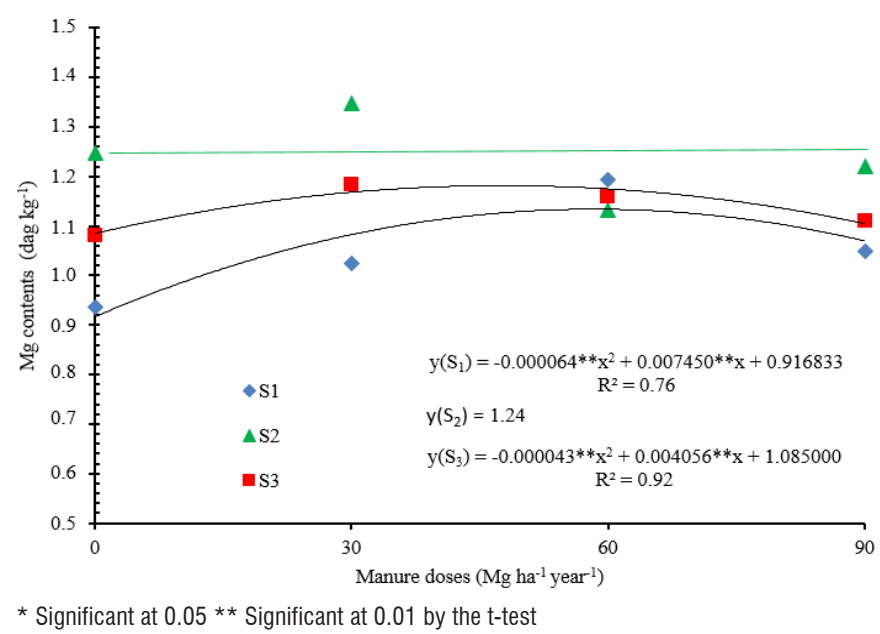

Figure 2. Contents of magnesium $(\mathrm{Mg})$ at 600 days after planting in cladodes of cactus pear cultivated at different spacings $\left(S_{1}=1.0 \times 0.5 ; S_{2}=2.0 \times 0.25\right.$ and $S_{3}=3.0 \times 1.0$ $\times 0.25 \mathrm{~m})$ and cattle manure doses

manure doses (Figure 1F), without interaction between these factors. The DMP values recorded for the spacings in single row of $1.0 \times 0.5 \mathrm{~m}$ and $2.0 \times 0.25 \mathrm{~m}$ were similar and superior to those obtained at the spacing in double row, $3.0 \times 1.0 \mathrm{x}$ $0.25 \mathrm{~m}$. Greater proximity between plants along the double row can favor a higher competition for nutrients, promoting lower growth, expressed by plant height and cladode area index (Donato et al., 2014), which are responsible for the formation of harvest and, consequently, lower DMP at these plant spacings. Cortazar et al. (2001) observed no difference in DMP as a function of biofertilizer doses, undoubtedly due to the low rainfall in the evaluated period $(330 \mathrm{~mm})$, which led to low mineralization of the added organic matter, resulting in low content of nutrients available to the plant.

The mean DMP varied quadratically as a function of the cattle manure doses (Figure 1F). High doses of $\mathrm{N}$ from the organic fertilization, of the order of 130 to $390 \mathrm{~kg} \mathrm{ha}^{-1}$ year $^{-1}$, may have caused this behavior. $\mathrm{N}$ promotes alterations in plant morphology and the large supply of this nutrient causes an increase in plant growth and leaf area (Marschner, 2012), which may represent lower content of dry matter in the tissues, which, combined with a reduction in green matter production, induced the decrease in dry matter production.

The results of the present study evidenced an increase in the contents of $\mathrm{P}, \mathrm{N}, \mathrm{K}$ and $\mathrm{S}$ in the cladodes of the 'Gigante' cactus pear with the increase in the cattle manure doses up to $90 \mathrm{Mg} \mathrm{ha}^{-1}$ year $^{-1}$. However, the model fitted to the dry matter production estimates that the maximum production, $21.8 \mathrm{Mg} \mathrm{ha}^{-1}$, is expected when $71.8 \mathrm{Mg} \mathrm{ha}^{-1}$ year $^{-1}$ of manure are applied, which confirms that adequate fertilization with cattle manure constitutes an efficient management strategy for this forage crop (Donato et al., 2014a,b), which is consistent with most areas of cactus pear, a crop that is basically of family farming.

\section{Conclusions}

1. The plant spacings and cattle manure doses independently influenced the contents of nutrients in the cladodes of 'Gigante' cactus pear.
2. The increase in cattle manure doses in 'Gigante' cactus pear increases the contents of phosphorus, nitrogen, potassium and sulfur in the cladodes.

3. The maximum production of cladode dry matter is estimated at $21.8 \mathrm{Mg} \mathrm{ha}^{-1}$ year $^{-1}$ with the manure dose of 71.8 $\mathrm{Mg} \mathrm{ha}^{-1}$ year $^{-1}$.

\section{Literature Cited}

Alves, R. N.; Farias, I.; Menezes, R. S. C.; Lira, M. A.; Santos, D. C. Produção de forragem pela palma após 19 anos sob diferentes intensidades de corte e espaçamentos. Revista Caatinga, v.20, p.38-44, 2007.

Caetano, L. C. S.; Carvalho, A. J. C. Efeito da adubação com boro e esterco bovino sobre a produtividade da figueira e as propriedades químicas do solo. Ciência Rural, v.36, p.1150-1155, 2006. http:// dx.doi.org/10.1590/S0103-84782006000400017

Casagrande, J. C.; Alleoni, L. R. F.; Camargo, O. A.; Borges, M. Adsorção de fosfato e sulfato em solos com cargas elétricas variáveis. Revista Brasileira de Ciência do Solo, v.27, p.51-59, 2003. http://dx.doi.org/10.1590/S0100-06832003000100006

Cavalcante, L. A. D.; Santos, G. R.; Silva, L. M.; Fagundes, J. L.; Silva, M. A. Respostas de genótipos de palma forrageira a diferentes densidades de cultivo. Pesquisa Agropecuária Tropical, v.44, p.424433, 2014. http://dx.doi.org/10.1590/S1983-40632014000400010 Cortázar, V. G.; Varnero, M. T.; Espinosa, M. Efecto de bioabono sobre el área fotosintéticamente activa, producción de cladodios y eficiencia de recuperación de $\mathrm{N}$ en un cultivo de tuna (Opuntia ficus-indica L.) en el primer año post-plantación. Journal of the Professional Association for Cactus Development, v.4, p.93-104, 2001.

Donato, P. E. R.; Pires, A. J. V.; Donato, S. L. R.; Bonomo, P.; Silva, J. A.; Aquino, A. A. Morfometria e rendimento da palma forrageira 'Gigante' sob diferentes espaçamentos e doses de adubação orgânica. Revista Brasileira de Ciências Agrárias, v.9, p.151-158, 2014a. http://dx.doi.org/10.5039/agraria.v9i1a3252

Donato, P. E. R.; Pires, A. J. V.; Donato, S. L. R.; Silva, J. A.; Aquino, A. A. Valor nutritivo da palma forrageira 'Gigante' cultivada sob diferentes espaçamentos e doses de esterco bovino. Revista Caatinga, v.27, p.163-172, 2014 b.

Dubeux Júnior, J. C. B.; Araújo Filho, J. T.; Santos, M. V. F.; Lira, M. A.; Santos, D. C.; Pessoa, R. A. S. Adubação mineral no crescimento e composição mineral da palma forrageira - Clone IPA-20. Revista Brasileira de Ciências Agrárias, v.5, p.129-135, 2010. http://dx.doi. org/10.5039/agraria.v5i1a591

Dubeux Júnior, J. C. B.; Santos, M. V. F.; Lira, M. A.; Santos, D. C.; Farias, I.; Lima, L. E.; Ferreira, R. L. C. Productivity of Opuntia ficus-indica (L.) Miller under different $\mathrm{N}$ and $\mathrm{P}$ fertilization and plant population in north-east Brazil. Journal of Arid Environments, v.67, p.357-372, 2006. http://dx.doi.org/10.1016/j. jaridenv.2006.02.015

EMBRAPA - Empresa Brasileira de Pesquisa Agropecuária. Sistema brasileiro de classificação de solos. 3.ed. Brasília: EMBRAPA, 2013.353p.

Fialho, J. S.; Aguiar, M. I.; Maia, L. S.; Magalhães, R. B.; Araujo, F. C.; Campanha, M. M.; Oliveira, T. S. Soil quality, resistance and resilience in traditional agricultural and agroforestry ecosystems in Brasil's semiarid region. African Journal of Agricultural Research, v.8, p.5020-5031, 2013. 
Geense, P.; Pattison, A. B.; Kukulies, T. L.; Scholberg, J. M. S.; Molina, A. B. Can changes in soil properties in organic banana production suppress fusarium wilt? Natural Resources, v.6, p.181-195, 2015. http://dx.doi.org/10.4236/nr.2015.63017

Marschner, P. Marschner's mineral nutrition of higher plants. 3.ed., London: Elsevier, 2012. 651p.

Novais, R. F.; Alvarez V., V. H.; Barros, N. F.; Fontes, L. E. F.; Neves, J. C. L. (ed.). Fertilidade do solo. 1.ed. Viçosa: Sociedade Brasileira de Ciência do Solo, 2007. 1017p.

Oliveira Júnior, S.; Barreiro Neto, M.; Ramos, J. P. F.; Leite, M. L. M. V.; Brito, E. A.; Nascimento, J. P. Crescimento vegetativo da palma forrageira (Opuntia ficus-indica) em função do espaçamento no Semiárido paraibano. Tecnologia e Ciência Agropecuária, v.3, p.7-12, 2009.

Silva, D. J.; Queiroz, A. C. Análise de alimentos: Métodos químicos e biológicos. 3.ed., Viçosa: UFV, 2009. 235p.

Silva, J. A.; Bonomo, P., Donato, S. L. R.; Pires, A. J. V.; Rosa, R. C. C.; Donato, P. E. R. Composição mineral em cladódios de palma forrageira sob diferentes espaçamentos e adubações química. Revista Brasileira de Ciências Agrárias, v.7, p.866-875, 2012. http://dx.doi.org/10.5039/agraria.v7isa2134
Silva, J. A.; Bonomo, P.; Donato, S. L. R.; Pires, A. J. V.; Silva, F. F.; Donato, P. E. R. Composição bromatológica de cladódios de palma forrageira sob diferentes espaçamentos e adubações químicas. Revista Brasileira de Ciências Agrárias, v.8, p.342-350, 2013. http://dx.doi.org/10.5039/agraria.v8i2a2431

Silva, L. M.; Fagundes, J. L.; Viegas, P. A. A.; Muniz, E. N.; Rangel, J. H. A.; Backes, A. A. Produtividade da palma forrageira cultivada em diferentes densidades de plantio. Ciência Rural, v.44, p.2064-2071, 2014. http://dx.doi.org/10.1590/0103-8478cr20131305

Silva, T. O.; Menezes, R. S. C.; Tiessen, H.; Sampaio, E. V. S. B.; Salcedo, I. H.; Silveira, L. M. Adubação orgânica da batata com esterco e, ou, Crotalaria juncea. I - Produtividade vegetal e estoque de nutrientes no solo a longo prazo. Revista Brasileira de Ciências do Solo, v.31, p.39-49, 2007. http://dx.doi.org/10.1590/S0100-06832007000100005

Souza, R. F; Faquim, V.; Torres, P. R. F.; Baliza, D. P. Calagem e adubação orgânica: Influência na adsorção de fósforo em solos. Revista Brasileira de Ciências do Solo, v.30, p.975-983, 2006. http://dx.doi.org/10.1590/S0100-06832006000600007

Zañudo-Hernández, J.; Aranda, E. G. C.; Ramírez-Hernández, B. C.; Pimienta-Barrios, E.; Castillo-Cruz, I.; Pimienta-Barrios, E. Ecophysiological responses of Opuntia to water stress under various semi-arid environments. Journal PACD, v,12, p.20-36, 2010. 